\title{
The ghostly matter of asylum in Kivu Ruhorahoza's A Tree Has Fallen (Europa)
}

\section{MaryEllen Higgins}

MaryEllen (Ellie) Higgins is Associate Professor of English at the Pennsylvania State University. Her books include The Western in the Global South, coedited with Rita Kerestezi and Dayna Oscherwitz, and Hollywood's Africa After 1994.

Email: mxh68@psu.edu

ORCID: https://orcid.org/0000-0002-2119-1630

DOI 10.17159/2309-9070/tvl.v.56i1.6269

\section{The ghostly matter of asylum in Kivu Ruhorahoza's A Tree Has Fallen (Europa)}

This paper applies Avery Gordon's insights in Ghostly Matters to Kivu Ruhorahoza's 2019 film, A Tree Has Fallen, and vice-versa. For Gordon, the ghost reveals visibility itself to be "a complex system of permissions and prohibitions." The ghost is a case, as Gordon puts it, of "visible invisibility," of seeing that one is not there. In Ruhorahoza's film, the protagonist, Simon, is an African asylum seeker in the UK, now a ghost. Even before he becomes ghostly matter, Simon is already ghostly: he is held in limbo, consistently denied, deemed threatening, highly visible yet rendered invisible, a figure whose claims to a past are deemed invalid in official channels. For Gordon, the ghost is a liminal presence, "what appears dead, but is nevertheless powerfully alive." In Ruhorahoza's film, the protagonist appears to be alive, but is nevertheless powerfully dead. Gordon notes the refusal of modern social scientists to acknowledge, or to speak to ghosts: what happens when British subjects speak to its African ghosts, and vice versa? This paper investigates what the ghostly relations in the film suggest about political subjectivity, visibility, and the politics of asylum. Potentially, the essay offers a reading of what may no longer be visible in Ruhorahoza's film, as the essay was written before Ruhorahoza edited A Tree Has Fallen, transformed it, and re-titled it Europa. Keywords: Kivu Ruhorahoza, Avery Gordon, asylum, African cinema, Ghostly Matters.

For Zygmunt Bauman, our present, liquid life instils fear of an uncertain expiration date in an environment of ubiquitous disposability. The haunting fear in liquid life, Bauman asserts, is that one will not adapt adequately enough to modernity's fluctuating demands, that one will be left behind-that one will "outstay [one's] welcome" (Bauman, Liquid Life 3). To narrate this liquid modernity, Bauman asserts, is not to tell the story of constantly emerging beginnings, but rather to "tell the story of successive endings" (Liquid Life 3).

The ghost resists an ending. The story of a ghost begins with an expiration of life, an expiration of breath, but it resists its expiration date, even if the ghost is a case, as Avery Gordon (42) puts it in Ghostly Matters, of seeing that one is not there. For Gordon, the ghost directs attention to, among other things, "what appears dead, but is nevertheless powerfully alive." As I watched Kivu Ruhorahoza's 2018 A Tree Has Fallen, a film about a ghost, I wondered what the filmmaker makes of that line. 
Avery's formula for the ghost-what appears dead, but is nevertheless powerfully alive-takes on another dimension in Ruhorahoza's film: its protagonist, Simon Adefolake (Oris Erhuero), appears to be very much alive- - he unlocks doors with his keys, takes a shower, walks the streets, makes dinner, has sex with his lover, talks to people who see, hear, and touch him—but he is nevertheless powerfully dead. The British subjects whom Simon's ghost haunts know that he is already dead; they are aware that he is a ghost-the task of the film's British subjects is then to speak with the African ghost, to piece together the meanings of his hauntings.

A Tree Has Fallen is a film, in the director's parlance, about dead black men who refuse to leave. ${ }^{1}$ Simon is a ghost who haunts politely, a ghost who is meant to be to invisible, but who dares to reveal himself and who refuses to play dead. He evokes Gordon's interpretation of haunting, which occurs "when things are not in their assigned places, when the cracks and rigging are exposed, when the people who are meant to be invisible show up without any sign of leaving" (xvi). Yet even before he becomes ghostly matter, even before he inhabits the ghost's body, Simon is already ghostly: he has barely survived civil conflict; he has lost his entire family in a massacre; he seeks asylum in the UK. He is treated, as Jonathan Darling (74) notes of asylum seekers, as a "liminal presenc[e] within the nation." The asylum seeker is held in limbo by the home office, a figure held precipitously at the edge of devastation, facing oppression in the home country if deported. Simon is subject to the sovereign's expiration date, to the space of "failed" asylum. His claims are consistently denied, and his appeal drags on for ten years. He is ultimately rejected, and is classified as an illegal being.

The zone of asylum is a ghostly zone. We see, in this film (and elsewhere), that the recognition of the seeker's political subjectivity in this zone is, to adapt Gordon, not there. The language of asylum packages political subjectivity not as a given, but as a thing given, a thing offered or denied by the sovereign who decides whether a person's fears and losses are valid, whether a person's narratives are to be believed, whether to send a person back into the realm of his or her oppressors. In Ruhorahoza's film, there is a flashback to Simon's audition for the part of Shylock in a play. He performs an improvisational scene set in an immigration appeals court in which his character makes his final plea for asylum. He recites these lines: "The home office have challenged my asylum claim. They have rejected all my appeals. They have expressed significant doubts about my story. Even my name, I've been told, is possibly not mine. But your Honor, I am who I have always claimed to be." Simon then lifts his shirt to reveal the scars produced by three bullet wounds on his stomach, and where each bullet entered his body—damaging his liver, perforating his stomach, and nearly hitting his spine-suturing the performance to his own life. Simon is compelled, in a climate of suspicion and denial that circulates a "colonialstyle set of assumptions about applicants' dishonesty," as Frances Webber (40) puts 
it, to assure his audience that his claim is not bogus: the wounds, he adds, "are not self-inflicted." Simon concludes with the lines, "Your honor, you can go ahead and dismiss everything that I've said, or you can listen to little voice of humanity deep inside of you, and give me back my life." Political subjectivity and rights become matters to be processed by the bureaucracy_cases that can be thrown out and disposed, things subject to expiration dates. The "adjudication of asylum claims," Elizabeth Dauphinee writes, manifests itself in "the relationship of a technology to its applications; it is the bits of paper that undergo judgment, and those that stand behind those bits of paper are denied their own faces, their own voices, their own skins. They appear before tribunals and are erased" (236); they are judged to be "ineligible for life" (237).

For Gordon, the ghost provides us with "fugitive knowledge," the ghost reveals what Foucault referred to as subjugated knowledge, or "what official knowledge represses within its own terms, institutions, and archives" (Gordon xviii). To express subjugated knowledge is a performance of citizenship; following Jacques Rancière, Engin F. Isin and Kim Rygiel argue that political subjectivity has always been enacted by people who make claims to rights they do not currently possess. In this proposition, despite being assigned to a zone that attempts to prevent him from acting as a political subject and citizen with economic, social, and political rights, Simon's very act of seeking rights is itself an act of political subjectivity and citizenship. Simon performs what Darling (77) refers to, in his analysis of asylum in the UK, as the "part with no part." Simon's protest against the subjugation of his narratives, of the suppression of his past by a home office that qualifies and disqualifies at will, a home office that can toss his claims and his rights in the dumpster, is an act of political subjectivity, an act of playing a part. However, this action, this agency in the film, has the aura of a ghostly performance, even if this scene of the audition in the film is a flashback to a moment when Simon is still alive. Simon is reduced to a supplicant pleading in a theatre for rights to be a part with a part, like an audition for existence.

The theatricality of the asylum zone plays out in the streets. One of the early figures to cross Simon's path is a man who drapes himself in the flag of Saint George (Dimitri Lambridis). The film visually notes the anti-immigrant, fortress identity politics of Brexit in this scene. It recalls Stuart Hall's description of a nation "haunted by the fantasy of a late return to the flag" (18). The flag is the visual incarnation of a discourse that makes particular claims to Britishness, and by extension, to resources and rights that are assumed to belong exclusively to those with legitimate claims to this version of Britishness. Simon gazes briefly at the flag-wrapped figure, who does not make eye contact. He passes Simon by as if he is invisible, as if he is not there, as if his ghost is not there. Yet Simon, and other postcolonial asylum seekers and immigrants, are very much there; they are at the core of the discourse on what it means to be British, of who is included and excluded, of who is welcome and where, 


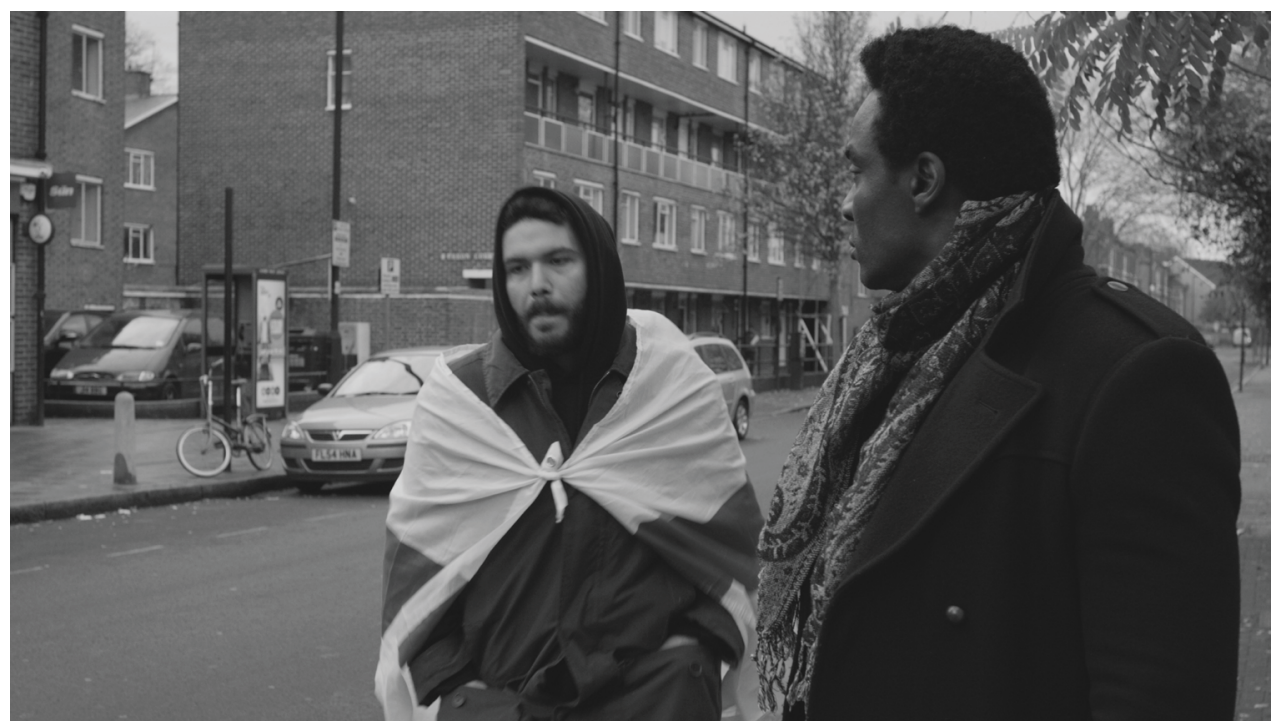

Figure 1: Man with flag of Saint George draped on his shoulders

and who has, to return to Bauman, outstayed one's welcome. While immigrants from formerly colonized spaces are depicted as "strangers at our door" (Bauman, Strangers at Our Door), they are not strangers to the histories of imperialism, to those ghostly, unsettled, and unsettling histories in which the question of who is host and who is guest, of who is foreign or strange, or who is allowed to make oneself at home in the world takes on multiple, entangled dimensions. ${ }^{2}$ As Paul Gilroy (110) writes, the postcolonial immigrant in melancholic Europe "is here because Britain, Europe, was once out there." ${ }^{3}$ And thus for Gilroy, the asylum seeker haunts, even if unwittingly: "It is the infrahuman political body of the immigrant rather than the body of the sovereign that comes to represent all the discomforting ambiguities of the Empire's painful and shameful but apparently nonetheless exhilarating history [...] the incomers may be unwanted and feared precisely because they are the unwitting bearers of the imperial and colonial past" (110). When the flag-bearer crosses paths with the ghost, it is not a moment of I see that you are not there, but a moment of "I treat you as if you do not exist," a moment of refusing to come to terms, as Gordon (18) writes, the "with what modern history has rendered ghostly."

When Simon is alive, the zone of asylum is a zone of estrangement. To make a living, Simon plays the role of the sexualizable black body available for consumption in a nightclub. His arms are bound and tied in glittery ribbons; his buttocks are bare and strapped in. Through Simon's voice-over, one learns that his family was attacked and killed on a night when he was dancing. He remembers the night in a flashback in which he performs an exotic dance as women drink, laugh, converse with each other, and gaze at him in vertical lines. His gesticulating movements on the floor are reminiscent of the opening scenes in Jean-Pierre Bekolo's Les Saignantes. 


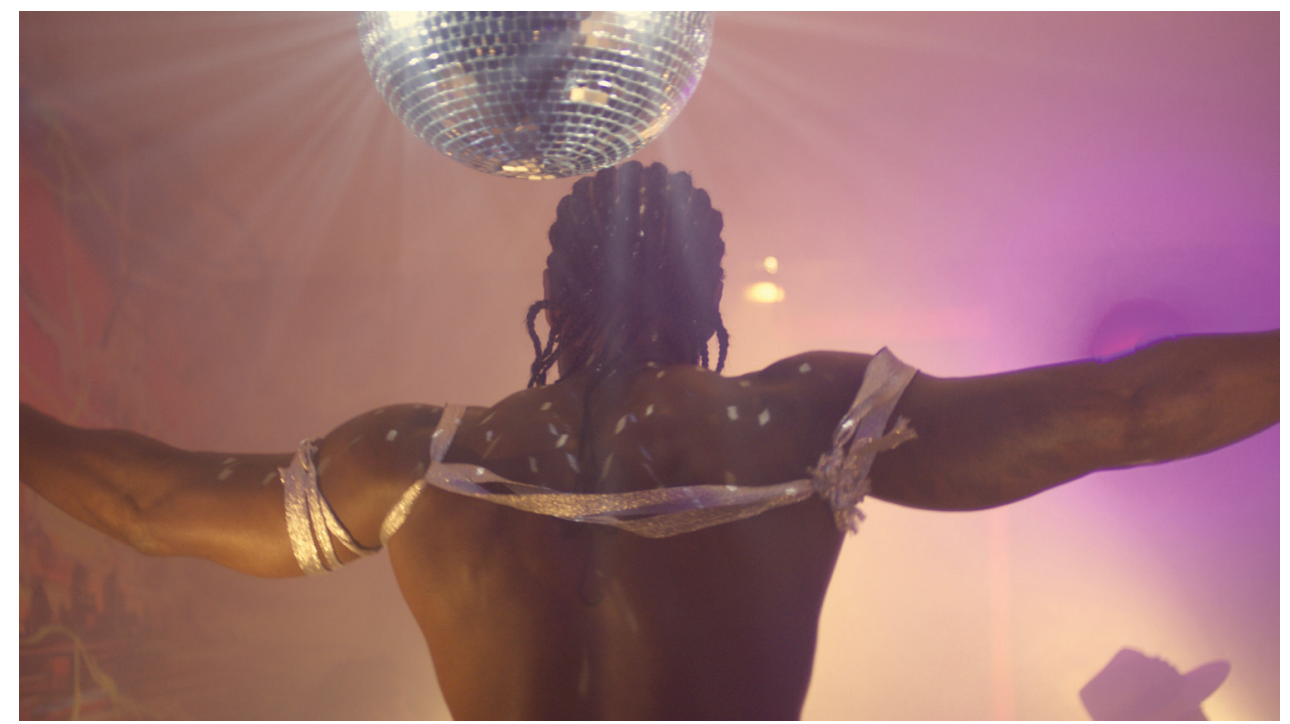

Figure 2: Bound: dance club scene

Yet this is not the "new anatomy" of Bekolo's oeuvre (see Omelsky). The bound and gyrating body is there, but it is not the decolonized, hyperbolized, and rebellious sex-worker/bloodette thrusting her body in a harness above the patriarch in Les Saignantes (see Harrow). Rather, in Ruhorahoza's rendering, Simon's public dance evokes an old, imprisoning mode of embodiment, one that simultaneously sexualizes and binds the black body. It is an aestheticized evocation of a bound past to the beat of techno-drumming, one that glosses over Simon's bullet wounds, eclipses the traces of his losses and injuries, and turns it into a performance choreographed for those who pay to watch with pleasure. This scene is there not to aestheticize the bound body, but to show how aestheticization is done, how the histories of Simon's bullet wounds and survivorhood are packaged in a spectacular ritual of pornographic, effacing entertainment.

Let's return, then, to Gordon's (18) question: "How do we reckon with what modern history has rendered ghostly?" Or, we might ask this question as Derrida does before Gordon, in Spectres of Marx: how do we apostrophize the ghost, or speak the language of the ghost? (12) In his ghostly form, Simon visits four people: Brother Joshua, who preaches in the street (Paul Morris), Simon's former landlady Peggy (Jennie Lathan), his lover Anna (Lisa Moorish), and Bruce Warnock (Matt Ray Brown), the co-director, with Anna, of the play for which Simon auditions. Bruce, who was once Anna's lover, stalks Anna and Simon, even following Anna to a poetry club after Simon's death, where she reads a poem in Simon's memory. Bruce spies on the ghost when he visits Anna; we see him gazing up to her apartment where they are having sex, and then lurking around a corner after they exit her apartment. Bruce seems to represent those in liquid modernity who channel 


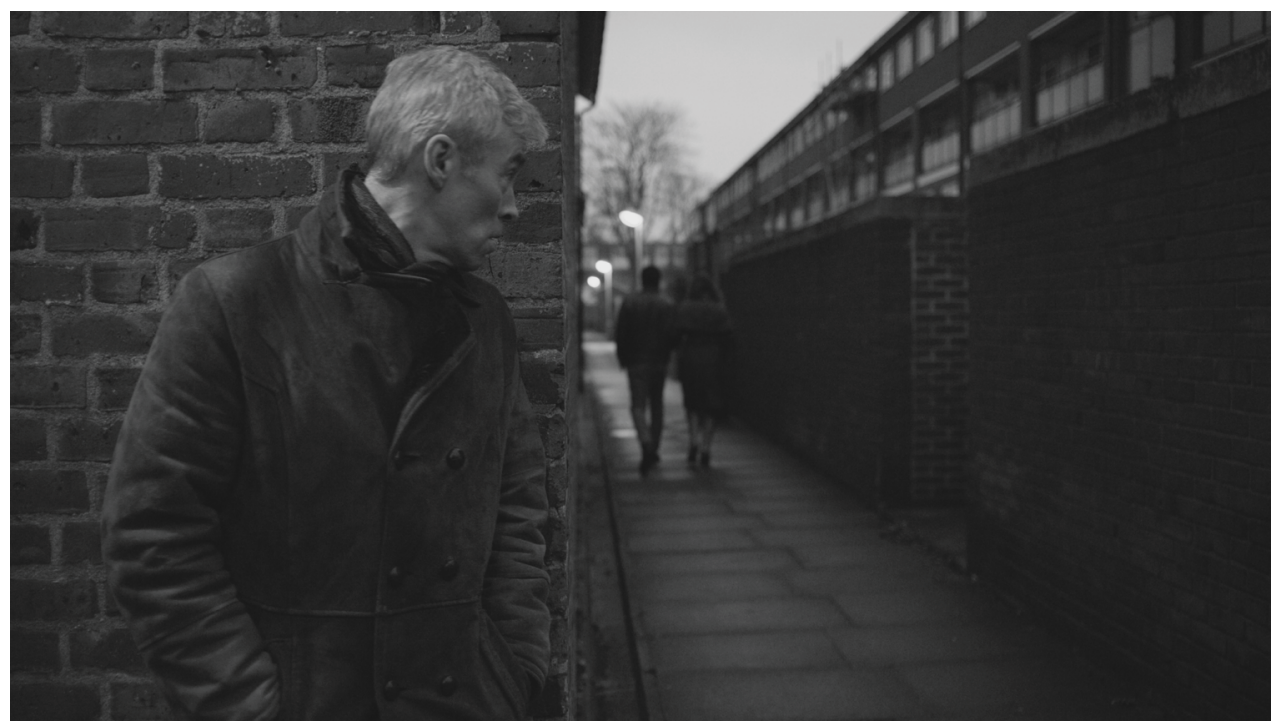

Figure 3: Bruce's surveillance

fears of their own pending disposability on others: after the grant proposal for his theatre project has been rejected by the Victoria Arts Fund, we see him kneel, and what look like bits of shredded paper pour out from his mouth as the text of the rejection letter scrolls on the screen. After the rejection, Bruce increasingly expresses his disdain for "others."

When Bruce addresses the topic of migration, he does not talk about Brexit or immigrants directly; instead, he talks about films. He dismisses Steven Frears' Dirty Pretty Things (2002), and particularly Nicolas Provost's film L'envahisseur (2011) (The Invader), as a waste of time. He tells Anna that he "hated that piece of shit" film, The Invader (a film about the relations between a rich woman and an undocumented African immigrant in Brussels). Bruce complains that the husband and female lead represent "everything that is wrong with Europe:" it is "sluggish, undignified, submissive." In an implicit reference to the stories of undocumented immigrants in Europe, he then asks how much of taxpayers' money has been spent on "fucking unbelievable," "tear-jerking diversity stories." As Bruce trivializes the plight of asylum seekers and others, his characterization of Europe echoes Kerry Moore's (349) analysis of discourses of asylum in the UK that position the British state as "manipulated and compromised, emasculated by the supposed 'abuse' of its immigration system and its failure to deal with an 'asylum crisis.'"

Yet Bruce's lament about what he sees as an emasculated Europe is less invested in his status as a British national than it is in another insecure attachment: losing his former lover Anna to Simon. Anna asks Bruce, "Why don't you just be honest about what it is that causes negativity and hostility toward everything that doesn't look like you?" The question remains open-Bruce may be displacing his frustration with his 
insignificance in liquid modernity — but if neoliberalism posits the "free, possessive individual" as its protagonist, as Stuart Hall (10) reminds us, Bruce is ultimately a man clinging possessively to that which he cannot possess. Anna is not his-she does not belong to anyone. Later in Ruhorahoza's film, in his ghostly form, Simon visits Bruce, who asks Simon what he wants from him, adding that the ghost has some "nerve" showing up at the door. Simon assures Bruce that he wants nothing from him, then speaks to him as if he is addressing the British sovereign about its possessive compulsions. Simon tells him,

You haven't lost anything, Bruce. You are still the powerful one. And that is how it is going to be for a very long, long time. All of this is yours. You are still the mighty one [...] We are all just trying to survive in a world you created for us. You are still the master of all of us-the master of dreams, beliefs, and narratives. If you think about it, that is all that counts, right? Dreams, beliefs, and narratives. But enough of that. I have come to forgive you [...] for being a patriot, for reporting an immigration crime, anonymously.

Bruce then orders him: "Get out of my house."

"Get out of my house:" words that suture the film narrative to the world just outside of the film, a world in which Prime Minister Teresa May and her supporters attempt to discourage immigration through the active production of a "hostile environment." The appellation "environment" leaves out the human activity that deliberately renders the social environment in the "home" toxic; the home policy is one of decided unwelcoming, designed to reinforce separateness and detachment, to bar people from having bank accounts or to work, to prevent the seeker from making a living, to disallow free movement, and to generate an atmosphere of rigorous estrangement. Susan Sontag, in Regarding the Pain of Others, imagined that photographs of distant tragedies - those tragedies from which asylum seekers try to escape-might animate in their viewers not mere sympathy, but a contemplation of how their own histories and privileges are linked to the suffering of the afflicted. In this case, when the afflicted are at the border, the regime of hostility aims to foster disregard for the pain of 'others' by dismissing their suffering altogether, and by disassociating the 'home' from politics 'over there.' In this theatre, 'others' are assigned the roles of the characters who only arrive to take. In one scene, Simon gazes at paintings in Anna's art gallery.

He lingers over two works. In both, individual human faces are distorted beyond recognition. As Simon gazes at these works, one can perceive another painting, this one of an elephant being lifted into the air in a harness. The space of Anna's gallery is a space of silent, visual recognition of the deliberate distortion of subjects, and in the backdrop an irony, a haunting, a reminder of the British Empire's extraction of the resources of those distant lands, of an imperial past and postcolonial present in 
which the right of the British subject to wander and to take is assumed as a given. These paintings, like the ghost, engage in a live haunting, a break with the illusion, as Gilroy (2) describes it, that "Britain has been or can be disconnected from its imperial past." Simon studies, with a pained expression, a painting of a tortured face bound at the neck, tongue hanging out. He gazes at another work in which paint has been smeared over the eyes and mouth, wiped over with sweeping strokes of the brush. The subjects in these paintings exist, but parts of their faces have been swept away. Their faces in the frame are now estranged faces-rearranged 'identities' - faces distorted beyond recognition. There is an irony in Simon's ghostly performance as a live being - and those who say there is no need for him to continue acting as if he were alive-for how does this powerfully dead, ghostly performance differ from the performance of Simon's living self, a self divested of his narratives? Indeed, as Dauphinee (236) writes, "In the [fictive] logic of the sovereign ban, death does not happen. The dead did not die if they were constituted as subjectless in the first place."

The effacement of subjectivity, however, is not the ending. Near the film's conclusion, Bruce enters Simon's apartment when Simon and Anna are having sex and he shoots Simon. It appears that Bruce has shot Simon's ghost. The ghost bleeds, but this is not the conclusion. Like the ghost, A Tree Has Fallen does not settle on an ending. It does not settle on the ghost's explanations of its final visits, or its reasons for leaving and then returning, or its death. There is a resistance to the denouement, to the successive ending. If there is a settling in this ghostly narrative-a settling and not an ending-the narrative settles on the movement of ghosts. Whereas the asylum seeker is hemmed in even as he or she makes profound claims to political subjectivity, the ghost is, as Amos Tutuola's work tells us, a wandering subject. In Achille Mbembe's (17) meditation on Tutuola, he asserts, "there is no body except in and through movement. That is why there is no subject but a wandering one. The wandering subject moves from one place to another. Journey as such does not need a precise destination: the wanderer can go about as he pleases." Mbembe's (or Tutuola's, if you accept the interpretation) wanderer recalls the foreign correspondents traipsing through the forests of Rwanda, who imagine themselves to be explorers in Ruhorahoza's 2015 film, Things of the Aimless Wanderer. The inequities of wandering subjecthood in A Tree Has Fallen come to the fore: Simon's ability to wander is only possible after death. The very first words of the film invoke a world inhabited by spirits without borders. Simon recites the poem in a voiceover, which includes this stanza:

The dead are never gone

They are in the paling shadow

They are in the thickening shadow

The dead are not under the water

They are in the rustling tree 
They are in the groaning wood

They are in the water that runs

And the water that sleeps

They are in the hut

They are in the crowd

The dead are not dead

This is Birago Diop's "Souffles," translated here by Ruhoroza himself for the film. The title can be rendered as "Spirits," and also "Breaths." We hear Simon's voice recite the poem as Anna stands silently on a rooftop; her hair moves in the wind. The poem evokes those wandering, breathing subjects, the ancestors. After his death, after the expiration of breath, Simon has the liberty to choose where he will wander, and while his remains are buried in his birthplace, he chooses to return to London. He is a dead black man who has the right to come back and to refuse to leave. As a ghost he is not only free to wander but to haunt, and as Gordon (xvi) writes, "Haunting is one way in which abusive systems of power make themselves known and their impacts felt in everyday life, especially when they are supposedly over and done with [...] or when their oppressive nature is denied." Haunting is a matter of seeing that which has been denied or reassigned out of consciousness, including the recognition of the imperial past and its enduring denial of the dignity of the formerly colonized. It is seeing that world, Simon asserts, created for us. This is a world in which, as Lucy Mayblin's (24) work on asylum shows us, "displacements resulting from colonialism and decolonisation in the past are left out of many accounts of the history of asylum policy that precede analyses of the present." In the discourse of this world, narratives of colonial and neocolonial persecution become ghostly matter: "it then also becomes logical to leave unmentioned the legacies of colonialism for refugee-producing situations, for destination country choice and for ongoing practices of border control" (24). For Simon, it is not only a matter of seeing how one is there but rendered invisible, or seeing what is supposed to be invisible, but a way of saying I have returned, I am everywhere: not only in the paling shadow, in the rustling tree, in the groaning wood, in the water that runs over the skin, in the crowd, in our intertwined histories, but at the front door, ringing the bell.

Rancière wrote this about politics: "Politics is generally seen as the set of procedures whereby the aggregation and consent of collectivities is achieved, the organization of powers, the distribution of places and roles, and the systems of legitimizing this distribution. I propose to give this system of distribution another name. I propose to call it the police" (28). If there is an alternate model for coexistence in the film that defies the social and spatial assignments managed by the police, it is the ancestors, moving. The ghost is not to be managed by any home office: can one deport an illegal ghost? Derrida (Spectres 11) says of the revenant, "One cannot control its comings 


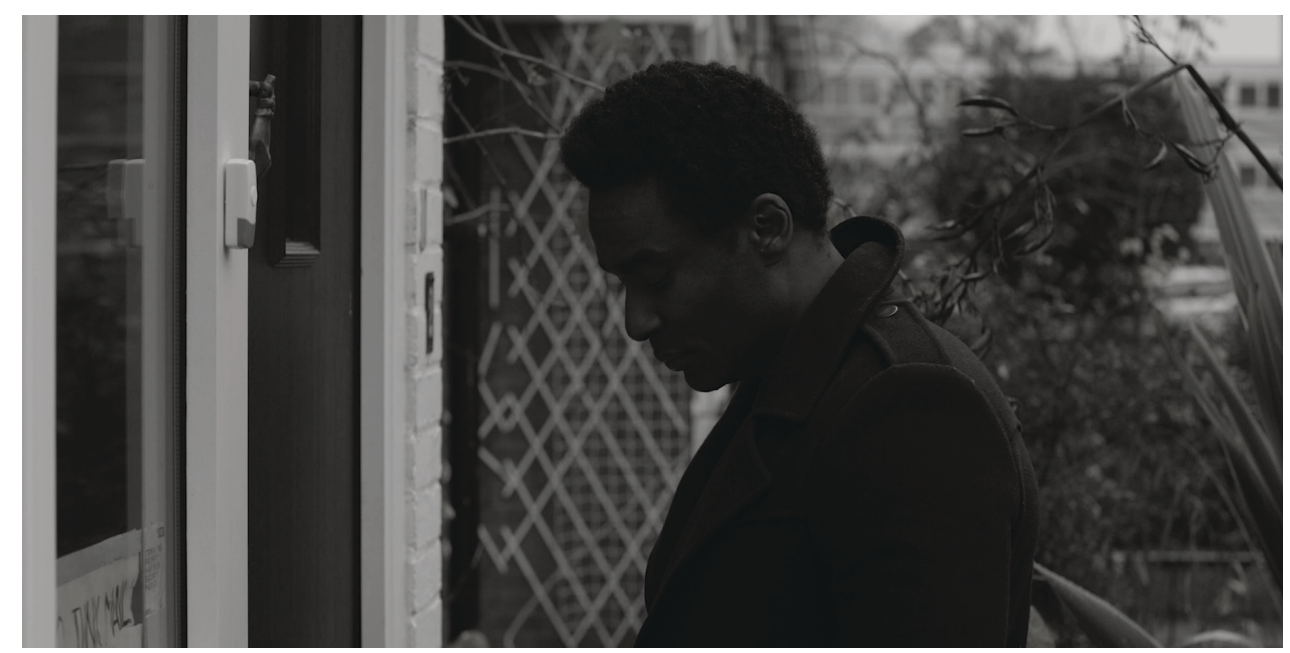

Figure 4: Simon at the door

and goings because it begins by coming back." There is an interesting divergence from what Derrida calls the specter's visor effect, that is, "we do not see who looks at us" (6). Derrida's model of the ghost is Hamlet's father whom we cannot see hidden behind his armour. Simon, in contrast, wanders in plain view; Anna feels his body against hers, he paints his former landlady's nails. What Derrida calls the ghost's "supreme insignia of power: the power to see without being seen" is stripped away.

In Ruhorahoza's incorporation of the ghost, it is not only a matter of seeing the ghost, or of following the ghost. Bruce follows the ghost in an attempt to police it. Simon the ghost, too, follows another ghostly figure on a bridge, whom he eventually loses. There is the compelling matter of speaking to the ghost, and listening to the ghost, but also of finally feeling the ghost, and of imagining how the ghost feels and is felt. This engagement in feeling begins by welcoming Simon at the door, and it is this feeling that disturbs Bruce the most. When Simon returns to Anna, she meets him at the door of her apartment. In the next scene they are naked; they have sex and his hands cling to the skin on her back; he cries holding her. The camera lingers on the skin of the lovers in an embrace. Skin is, as Marc Lafrance (9) writes, an "instrument of interpersonal engagement and exchange." During Simon's visit with Peggy, we do not see Peggy's face, initially. The first image of their meeting is a shot of their hands. Simon holds Peggy's hand and gently runs his thumb over her knuckles, over her aging skin. When we see her face she seems to hold back tears; Simon strokes her forehead. Peggy has been alone; her family exists but does not visit her. Simon prepares her a bath, soaps and runs water over her skin, washes her hair, and massages lotion on her feet. The attendance to the needs of the body and the care of the skin relay a welcoming, an intimate friendship, a way of sharing space that is felt first in the skin. Close-up scenes of Simon's tender care of Peggy's 
skin occur before they exchange any words. Peggy discloses that she has missed his kindness and his home-cooked meals; Simon apologizes for leaving suddenly. She tries to assure him that it is okay; he opens a window and magically creates an image of light. They are not denied, to return to Dauphinee, their own skins. These scenes lie in a stark contrast to the dance club scene in which Simon's body and tattooed skin are put on display. In the club there is no connection, no magic between Simon and the anonymous women who smile at him during his pornographic performance, no intimate connection when a woman briefly stops her conversation to touch his skin as he dances suggestively. Also in contrast is Bruce, who protects his skin and conceals its porousness: in the final scenes, he rides about the streets fully covered in his motorcycle gear and helmet. The skin, Lafrance (9) writes, is not a mere "crude container, a one-sided shield, or an impenetrable shield." Rather, as Sara Ahmed and Jackie Stacey write, it "has the potential to break down the dichotomous elaborations of inside/outside, surface/depth and self-other that often permeate accounts of embodied subjectivity" (qtd in Lafrance 11). It is Simon's affectionate attachments to others, the welcome touches of the skin, that Bruce cannot manage, and tries desperately to police.

The model of the borderless world of the ancestors is likewise a stark contrast to present zones of managed, policed existence: one's belonging in the world of the ancestors is uncontested. Yet the proposition of being free to wander only after death is rather unsettling. Simon returns as a witness "from the inside of death," to adapt Dauphinee (231). He is free to wander where he pleases, but the living are still there in their ghostly zones, where they can be reduced to the status of threats, problems, frauds, financial burdens, crisis, overflow-where they can be returned to other zones, as Dauphinee writes, where they may be imprisoned, tortured, or murdered by those whom they fled in the first place. To expand upon Gordon's question, how do we reckon with the alienating zones that render living people ghostly? In the film's initial scenes after the recitation of Diop's poem about spirits, we see Simon sitting still on a train, fatigued, passing through high-rise apartment buildings, in a seat that propels him backward. There are no sounds of voices, only the motion of the train. He evokes Benjamin's angel of history, his face gazing back at the world. But he is a ghost. We cannot yet know, at this point, that he is ghostly matter.

Several claims are made upon ghosts; ghosts, too, have their assigned roles. In Derrida, "the dead are dead [...] Just because the dead no longer exist does not mean that we are done with spectres" (Derrida and Stiegler 49). For Gordon (xix), the ghost is a messenger: it reveals to us a "living inheritance." When the ghost appears, Gordon (xvi) asserts, "We are notified that what's been concealed is very much alive and present." In the film, Simon explains that after a death, one does not say that someone is dead. When one joins the other world, one says that a tree has fallen. In a similar vein, at the ending of the film, one does not speak of an ending. We hear 


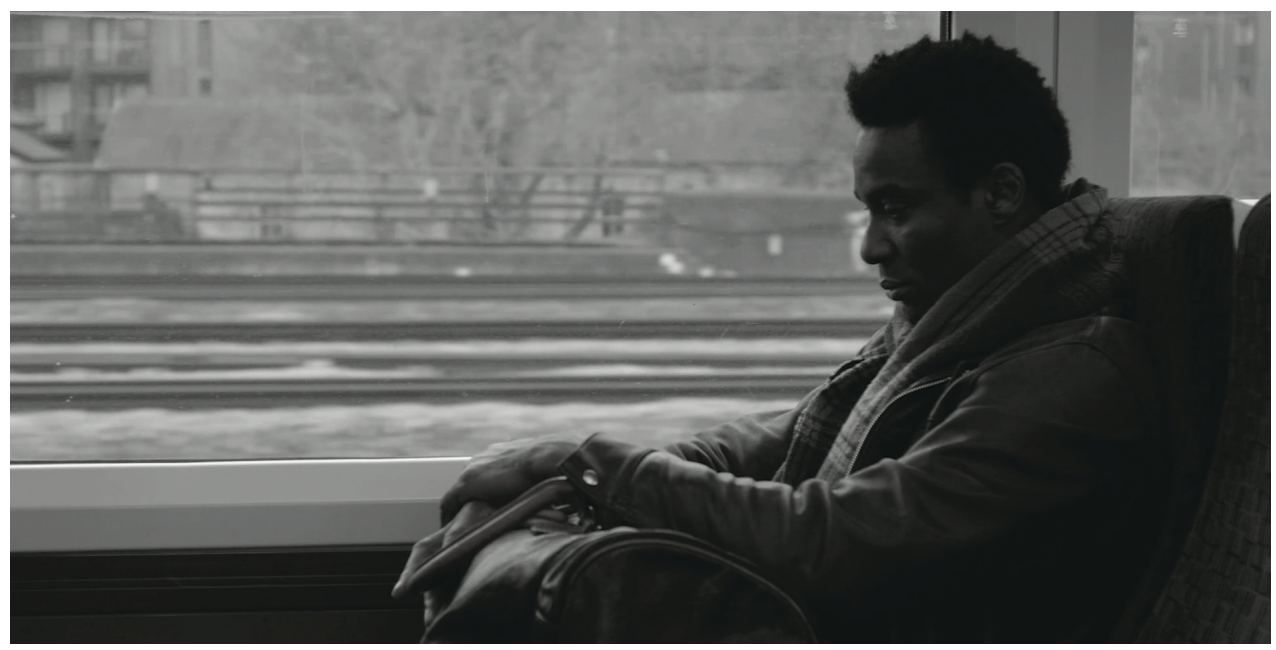

Figure 5: Simon on the train

Simon's voice return to Diop's "Souffles" as Anna is walking. Among the last lines are:

They are in the forest;

They are in the house.

The dead are not dead.

Hear things more than beings.

The voice of fire you can hear.

Hear the voice of water.

Hear the weeping bush in the wind.

It is the breath of the ancestors.

Gordon (6) writes that "[c]ajoling is in the nature of the ghost, the very distinctions between there and not there, past and present, force and shape." The film itself is ghostly. It disorients: in one moment Simon stoops to leave flowers near an apartment building, looks up to the rooftop, and there is a cut to a view of the rooftop from below, then a cut to an image of Simon on a roof. We see him from the back, in a different coat, looking down. Is this the roof the ghost has been looking at? Did Simon jump from it in the time before? Answers are withheld. Then a cut to Anna, on a rooftop, perhaps the same one but the view has changed. She stands where we saw her before, at the beginning of the film, in the same coat. What else happens on the roof is not spoken or seen.

I am writing about a film that, at this moment, like a ghost, only a few have seen. I've seen the fifth cut. Further cuts might make some of these words on the page appear as if I have seen something that is not there. But they existed. And perhaps a new image will appear, and I will have missed it, until it appears before me. In between the writing of this piece and my "proofs," Ruhorahoza added several new 
scenes to A Tree Has Fallen, transformed it, and re-titled it Europa. Europa is a film altered and rearranged: the story about Simon is still there, alongside an artful mix of ghostly fiction, quasi-ethnography, explication du texte, sociological documentary, and an autobiographical essay about an African filmmaker making a film out of Africa titled A Tree Has Fallen. Potentially, then, this essay offers a reading of what may no longer be visible in Ruhorahoza's film. In any event, "to write stories concerning inclusions and exclusions," Gordon (17) asserts, "is to write ghost stories." A Tree Has Fallen presents narratives, memories, suggestions, and omissions. A ghost story. It displays the sounds and images of wind that rustles branches, of water caressing the skin, of fires, spirits, and of breath. They are there and not there, past and present, expiring and breathing — shape, image, sound, summoning.

\section{Acknowledgments}

I would like to thank Kivu Ruhorahoza for sharing the various versions of his films with me and for providing the film stills that accompany this essay.

\section{Notes}

1. From an email correspondence with the director, 2018.

2. I make a reference here to Jacques Derrida's Of Hospitality: Anne Dufourmantelle Invites Jacques Derrida to Respond (2000). My reading of Derrida in this instance is inspired by Joshua Mills-Knutsen's questions about hosts, guests, and foreigners in his article, "Becoming Stranger".

3. The phrase "We are here because you were there" was also articulated by Ambalavaner Sivanandan (see Younge).

\section{Works Cited}

Bauman, Zygmunt. Liquid Life. Polity, 2005. . Strangers at Our Door. Polity, 2016.

Darling, Jonathan. "Asylum and the Post-Political: Domopolitics, Depoliticisation and Acts of Citizenship: Asylum and the Post-Political." Antipode vol. 46, no. 1, 2014, pp. 72-91. DOI: https://doi.org/10.1111/ anti.12026.

Dauphinee, Elizabeth. "Living, Dying, Surviving II." The Logics of Biopower and the War on Terror. Eds. Elizabeth Dauphinee \& Cristina Masters. Palgrave Macmilllan, 2007.

Derrida, Jacques. Of Hospitality: Anne Dufourmantelle Invites Jacques Derrida to Respond. Trans. Rachel Bowlby. Stanford U P, 2000. . Spectres of Marx. Trans. Peggy Kamuf. Routledge, 1994.

Derrida, Jacques \& Bernard Stiegler. "Spectographies." The Spectralities Reader: Ghosts and Haunting in Contemporary Cultural Theory. Eds. María del Pilar Blanco \& Esther Peeren. Bloomsbury, 2013, pp. 38-51.

Gilroy, Paul. After Empire: Melancholia or Convivial Culture? Routledge, 2004.

Gordon, Avery F. Ghostly Matters: Haunting and the Sociological Imagination. U of Minnesota P, 2008.

Hall, Stuart. "The Neoliberal Revolution." Soundings no. 48, 2011, pp. 9-27. https://www.lwbooks.co.uk/ soundings/48/neoliberal-revolution. Accessed 19 Feb. 2019.

Harrow, Ken. “'Let Me Tell You about Bekolo's Latest Film, Les Saignantes, but First ...'” Exit: Endings and New Beginnings in Literature and Life. Eds. Stefan Helgesson, et al. Rodopi, 2011.

Henderson, Ailsa, et al. "How Brexit Was Made in England." The British Journal of Politics and International Relations vol. 19, no. 4, 2017, pp. 631-46. DOI: https://doi.org/10.1177/1369148117730542.

Isin, Engin F. \& Kim Rygiel. "Abject Spaces: Frontiers, Zones, Camps." The Logics of Biopower and the War on Terror. Eds. Elizabeth Dauphinee \& Cristina Masters. Palgrave Macmillan, 2007. 
Lafrance, Marc. "Skin Studies: Past, Present, and Future." Body and Society vol. 24, no. 1-2, 2018, pp. 3-32. DOI: https://doi.org/10.1177/1357034X18763065.

Mayblin, Lucy. Asylum After Empire: Colonial Legacies in the Politics of Asylum Seeking. Rowman \& Littlefield, 2017.

Mbembe, Achille. "Life, Sovereignty, and Terror in the Fiction of Amos Tutuola." Research in African Literatures vol. 34, no. 4, 2003, pp. 1-26. https://www.jstor.org/stable/4618325. Accessed 19 Feb. 2019.

Mills-Knutsen, Joshua. "Becoming Stranger: Defending the Ethics of Absolute Hospitality in a Potentially Hostile World." Religion and the Arts vol. 14, 2010, pp. 522-33. DOI: https://doi.org/10.1163/156852910X529304.

Moore, Kerry. “'Asylum Shopping' in the Neoliberal Social Imaginary." Media, Culture \& Society vol. 35, no. 3, 2013, pp. 348-65. DOI: https://doi.org/10.1177/0163443712472090.

Omelsky, Matthew. "Jean-Pierre Bekolo's African Cyborgian Thought." Nka: Journal of Contemporary African Art vol. 31, no. 1, 2012, pp. 6-21. DOI: https://doi.org/10.1215/10757163-1586445.

Rancière, Jacques. Disagreement: Politics and Philosophy, trans. Julie Rose. London: Verso, 1999.

Ruhorahoza, Kivu \& Antonio Ruberio. Sundance Interview: The Story of "Things of the Aimless Wanderer." https:// www.youtube.com/watch?v=Hc X6PkEC1M. Accessed 19 Feb. 2019.

Webber, Frances. "Borderline Justice." Race \& Class vol. 54, no. 2, 2012, pp. 39-54. DOI: https://doi. org $/ 10.1177 / 0306396812454988$.

Younge, Gary. "Ambalavaner Sivanandan Obituary: Director of the Institute of Race Relations Who Helped Change the Way Britain Thought About Race.” The Guardian. 7 Feb. 2018. https://www.theguardian.com/ world/2018/feb/07/ambalavaner-sivanandan. Accessed 11 Jul. 2018. 